Revised version, cite as: Lombardo, U., Rodrigues, L., Veit, H., 2018. Alluvial plain dynamics and human occupation in SW Amazonia during the Holocene: A paleosol-based reconstruction, Quaternary Science Reviews 180, 30-41.

\title{
Alluvial plain dynamics and human occupation in SW Amazonia during the Holocene: a paleosol-based reconstruction.
}

\author{
Umberto Lombardo ${ }^{1 *}$, Leonor Rodrigues ${ }^{2}$, Heinz Veit $^{3}$ \\ $1^{*}$ University of Pompeu Fabra, Ramon Trias Fargas 25-27, Mercè Rodoreda ES-08005m \\ Barcelona. \\ ${ }^{2}$ Centre d'Ecologie Fonctionnelle et Evolutive, CNRS, 1919 Route de Mende - 34230 \\ Montpellier \\ ${ }^{3}$ Institute of Geography, University of Bern, Hallerstrasse 12, CH-3012 Bern \\ ${ }^{*}$ Corresponding author. \\ E-mail address: umberto.lombardo@upf.edu
}

\begin{abstract}
The present study reconstructs Holocene fluvial dynamics in the southern Amazonian foreland basin through the analysis of 36 stratigraphic profiles taken along a $300 \mathrm{~km}$ long transect across the Llanos de Moxos (LM), in the Bolivian Amazon. Based on 50 radiocarbon ages from paleosols intercalated with fluvial sediments, the most important changes in floodplain dynamics on a millennial scale are reconstructed and the links between pre-Columbian cultural processes and environmental change in the region explored. Results show that the frequency of river avulsions and crevasses, as inferred from the number and age of the cored paleosols, is stable from $8 k$ cal. yrs BP to $4 k$ cal. yrs BP and increases significantly from $4 k$ to $2 k$ cal. yrs BP, following the strengthening of el Niño/la Niña cycle and an increase in average precipitation. Fluvial activity then decreases and reaches its minimum after $2 \mathrm{k}$ cal BP. A comparison between the stratigraphic record and the archaeological record shows a match between periods of landscape stability in SW Amazonia (low river activity) and periods of pre-Columbian human occupation. The first Amazonians lived in the LM until $4 k$ yrs. BP, when an abrupt increase in the frequency of river avulsions and crevasses forced the abandonment of the region. After two thousand years of archaeological hiatus, which matches the period of highest river activity in the region, agriculturists reoccupied the Bolivian Amazon.
\end{abstract}

\section{Keywords}

Holocene, Paleogeography, South America, Amazonia, Paleosol, Human-environment interactions, Rivers, 


\section{Introduction}

The Llanos de Moxos (LM), an extensive savannah that covers most of the Bolivian Amazon, covers an important part of the South American wetlands and provides valuable ecological services (Junk, 2013; Melack and Hess, 2011). It is a fragile hydrological system, increasingly threatened by global warming and human activity (Junk, 2013; Müller et al., 2011; Pacheco, 2006). The landscape of the LM is constantly being reshaped by the region's very active rivers, with important implications for local livelihoods and biodiversity (Lombardo, 2016, 2017). The LM is home to a rich biodiversity, including several endemic species (Langstroth, 2011), and it is the area in Amazonia with the highest cultural and genetic diversity among its modern indigenous populations (Bert et al., 2004; Crevels and van der Voort, 2008). The LM is also known for its archaeological heritage, amongst the most important in Amazonia (Erickson and Walker, 2009; Lombardo et al., 2013a; Lombardo and Prümers, 2010; Prümers and Jaimes Betancourt, 2014). Despite the LM's ecological and cultural significance, very little is known about how the landscape here has evolved during the Holocene. Reconstructing the evolution of the landscape is key in order to understand the links between pre-Columbian cultural processes and environmental change in the region; the origin of its modern landscape and biodiversity; and the potential changes they could undergo due to global warming and other anthropogenic pressures. The extent to which changes in the natural environment have influenced pre-Columbian cultural trajectories, and vice versa, is a controversial and much debated topic amongst Amazonian archaeologists and paleoecologists (Bush and Silman, 2007; Erickson, 2008; Lombardo et al., 2015; Meggers, 1971, 2007; Sponsel, 1986). While some scholars have downplayed the importance of the environment in shaping pre-Columbian cultural trajectories in the LM (Erickson, 2008), others have argued that climate change had a direct impact on the archaeological record because of the changes it induced on vegetation (Carson et al., 2014; Iriarte et al., 2017) or the disruption brought about by changes in the ENSO cycle (Lombardo et al., 2011a; Meggers, 2007; Rodrigues et al., 2016). It has also been argued that, in Amazonia, river activity has had an important impact on the evolution of the landscape (Kalliola et al., 1992; Lombardo, 2016; Salo et al., 1986) and local livelihoods (Lathrap, 1968; Pärssinen et al., 1996). Rivers have a paramount role in controlling many fundamental aspects of Amazonian ecology (Ayres and Clutton-Brock, 1992; Ferreira and Stohlgren, 1999; Remsen and Parker, 1983). Rivers are also of great importance for local populations, providing aquatic resources, fertile land for agriculture and waterways for transportation (Junk, 1984; Marengo, 2008; McGrath et al., 1993). Archeological research has shown that, in Amazonia, rivers greatly influenced pre-historic settlement patterns too (Denevan, 1996; McMichael et al., 2014; Neves, 2008).

However, with a few exceptions (Lathrap, 1968; Lombardo et al., 2012; Neves, 2008; Pärssinen et al., 1996), the relationship between changes in river dynamics and pre-Columbian settlement patters in Amazonia has been largely overlooked in the literature.

Given the LM's highly active rivers (Aalto et al., 2002; Aalto et al., 2003; Gautier et al., 2010; Hanagarth, 1993; Lombardo, 2014, 2016, 2017; Plotzki et al., 2015; Schwendel et al., 2015) and the importance of the region's archaeological record (Erickson, 2000; Jaimes Betancourt, 2013; Lombardo and Prümers, 2010; Lombardo et al., 2013b; Prümers and Jaimes Betancourt, 2014; Rodrigues et al., 2015; Rodrigues et al., 2016; Walker, 2004), the LM offers an excellent study 
area to investigate the relationships between river dynamics, landscape evolution and human histories.

Recent archaeological research shows that the eastern LM were inhabited since the early Holocene until about $4 \mathrm{k}$ cal yrs BP (Lombardo et al., 2013b). Beside hunting and gathering, these first inhabitants cultivated maize (Brugger et al., 2016) and even domesticated rice (Hilbert et al., 2017). Abundant archaeological evidence suggests that complex societies repopulated this area, known as the Monumental Mounds Region (MMR) (Lombardo et al., 2013a), in 2k cal yrs BP until the arrival of the Spaniards (Carson et al., 2014; Erickson, 2000; Lombardo and Prümers, 2010; Prümers and Jaimes Betancourt, 2014; Whitney et al., 2014). Between these two periods of occupation, there is an archaeological hiatus of about 2000 years. It has been suggested that this hiatus was related to a period of increased fluvial activity during which Río Grande deposited a sedimentary lobe that covered early and mid-Holocene archaeological sites (Lombardo et al., 2013b) and created the conditions for the later development of the Monumental Mounds culture (Lombardo et al., 2013a; Lombardo et al., 2015; Lombardo et al., 2012). However, it is as yet unclear whether the increased activity of Río Grande was an isolated phenomenon, due to intrabasinal processes, with localized effects; or if it was part of a larger scale change in river behavior that affected the whole of the Bolivian Amazon, and, if so, what triggered this large-scale change.

In this study we aim to identify which parts of the early Holocene landscape were covered with mid or late Holocene alluvia. We discuss the implications of our findings in terms of 1 ) the evolution of the landscape in the Bolivian Amazon and the possible triggers of change in river activity (to what extent crevasse splays and river avulsions were controlled by climate, tectonics or were the result of intrabasinal processes); and 2) the impact of this change on preColumbian settlement patterns and the preservation of the archaeological record.

\section{Study area}

The Llanos de Moxos (LM), an approximately 150,000 $\mathrm{km}^{2}$ seasonally flooded savannah in the Bolivian Amazon (located between $12^{\circ} \mathrm{S}$ and $16^{\circ} \mathrm{S}$ ), is the foredeep of the southern Amazonian foreland basin (Figure 1). It is bordered by the central Andes, to the W-SW, and the Brazilian Shield, to the E. The Brazilian Shield dips gently towards the Andes, underlying unconsolidated sediments (Hanagarth, 1993; Plafker, 1964). The annual rainfall, ranges from $1200 \mathrm{~mm}$ in the northeastern LM to $3500 \mathrm{~mm}$ in the southern LM (Hijmanns et al., 2005). Rainfall is concentrated between November and April. Evapotranspiration is estimated to be $1220 \mathrm{~mm}$ (Roche et al., 1991). Temperatures are high throughout the year, with an average of 25 Co. From June to September, short-lived incursions of cold fronts from the south, locally called Surazos, can occasionally cause sharp drops in temperature. The extent of the flooded area varies greatly every year, ranging between $30000 \mathrm{~km} 2$ and $80000 \mathrm{~km}^{2}$ (Hamilton et al., 2004). Very little is known about the stratigraphy and thickness of these foreland deposits. The region is drained by three rivers: the Mamoré, the Beni and the Iténez Rivers. These three rivers converge with the Madre de Dios River to form the Madeira River, which is the largest tributary of the Amazon River. In the central and southern LM, the landscape is characterized by savannahs crisscrossed by strips of forest growing on river levees and paleo-levees. Here, 
the forest-savannah boundary is controlled by the local topography, with annual cycles of seasonal floods and severe drought that impede tree growth in the low-lying savannah and trees growing on relatively elevated fluvial levees (Mayle et al., 2007). The drainage of the LM is impeded by the region being almost completely flat, with an average slope of $10 \mathrm{~cm}$ per $\mathrm{Km}$ (Lombardo et al., 2012). This is partly due to the fact that the northern part of the Bolivian Amazon is uplifting (Dumont and Fournier, 1994; Lombardo, 2014).

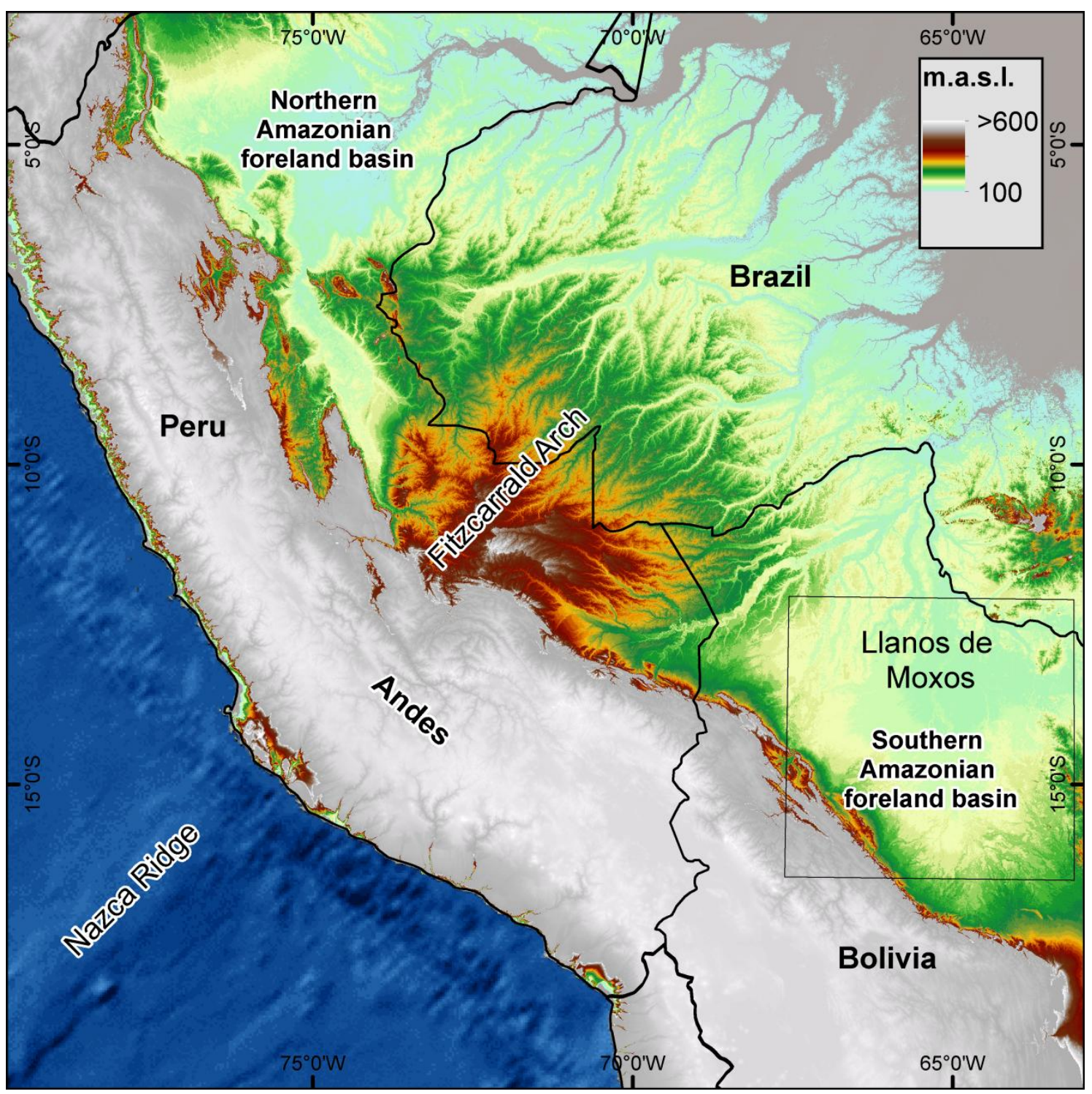

Figure 1 Topographic map of western South America with some important geological features. The south-eastern part of the Fitzcarrald Arch constitutes the LM's north-western border, which, together with the Brazilian Shield, to the north-east of the LM, forms a continuous barrier which impedes the drainage of the LM (see Lombardo, 2014). The box identifies the study area, shown in Fig. $2 \mathrm{~A}$.

\section{Methods}

In order to investigate how the southern Bolivian Amazon changed throughout the Holocene and what processes controlled these changes, we looked at 36 stratigraphic profiles across the southern LM, along a $300 \mathrm{~km}$ long transect from the pre-Andes to the eastern LM (Fig 2). Most 
of the paleosols have been radiocarbon dated. Stratigraphic profiles comprehend four river outcrops (518,481, 499 and 35), one dug profile (SB_29), one dug profile plus auger (296), two profiles from pits excavated with heavy machinery for road maintenance (40 and 480) and 17 stratigraphic profiles obtained with a Wacker vibra-corer. Description of grainsize, hydromorphic features and identification of stratigraphic units are based on field observation. Five sub-regions have been defined. In three cases, cores 518, Estan and 296, stratigraphic information is partially or completely missing, nevertheles the cores have been included because they document the presence or absence of paleosols. The pre-Andes sub-region includes the two most western profiles, which are closer to the Andes and outside the influence of the larger rivers. Two other sub-regions, the Maniqui and the Sécure, have been defined based on the spatial distribution of the paleorivers observable in satellite imagery (Lombardo, 2016). The Mamoré sub-region is defined based on its geographical closeness to the Mamoré River and the similarity of its stratigraphy with published stratigraphy along the Mamoré river banks (May et al., 2015). Finally, the Río Grande sub-region is defined as the area covered by this river's paleochannels and the late Holocene sedimentary lobe, as described in Lombardo et al. (2012) and in Plotzki et al. (2015).

Radiocarbon dating was done in three different laboratories: the Poznan Radiocarbon Laboratory (POZ), the Direct AMS (D-AMS) and the LARA AMS Laboratory (LARA). Radiocarbon ages have been calibrated with CALIB 7.1 (http://calib.qub.ac.uk/calib/calib.html) using the SHCal13 calibration curve (Hogg et al., 2013). For the $\mathrm{C} / \mathrm{N}$ analysis, $20 \mathrm{~g}$ of each sample were sieved through a $2 \mathrm{~mm}$ sieve and milled. Concentrations of $\mathrm{C}$ and $\mathrm{N}$ were measured by dry combustion and gas chromatographic separation with a CNS analyser.

32 paleosols have been radiocarbon dated, obtaining a total of 50 ages (Table1). To radiocarbon date organic matter contained in paleosols is problematic, as the ages reflect the mean residence time of the organic matter plus the time of the burial (Wang et al., 1996). Therefore, radiocarbon ages of paleosols tend to overestimate the moment of the burial. Inconsistences between radiocarbon ages of humin and humate fractions can occur, often due to contamination with younger material from the soil above or older material such as charcoal or other fire-derived compounds that became incorporated in the soil. In our samples we often find discrepancies between ages of the residual (RES) fraction (humins) and ages of the soluble (SOL) fraction (humates), with important differences in cores SB_29, 415, 416, 440 and B1-247. In the case of the samples from cores 415 and 416 , for which both the SOL and the bulk fractions were measured, the age of the bulk fraction is similar to the age of the SOL fraction. In the case of paleosols from cores 442, 447, 416 and 418 there were not enough humins to be extracted for AMS measurement of the RES fraction (see Table 1). When differences between the ages of the RES fraction (older) and the SOL fraction (younger) in soils and paleosols are found, the age of the RES fraction is normally considered more reliable than the humates, as the latter are easily contaminated with material from the topsoil (Goh and Molloy, 1978; Lowe and Walker, 1997). However, this might not be the case of the paleosols here described. The very low C:N values (Table 1) indicate high decomposition rates (Post et al., 1985), suggesting that organic matter in these tropical paleosols is almost completely degraded and humified by bacterial activity (Meentemeyer, 1978). Therefore, the RES fraction is likely to consist of the most recalcitrant materials to bacterial decomposition and its age could be strongly dependent on the presence of fire derived compounds (Schmidt et al., 2011). This could explain the large 
discrepancies in many of the RES/SOL coupled dating, as most of the RES signal probably derives from old, fire-derived recalcitrant material, thus being a better representation of the average age of the paleosol than the age at which the paleosol was buried. It is unlikely that the SOL fraction age is a result of contamination from upper layers as it is similar to the age of the bulk fraction, suggesting that humic and fulvic acids account for most of the organic matter in these paleosols. If the age of the SOL fraction was the result of contamination, most of the organic carbon stored in the paleosol should have originated in the upper level. However, all the paleosols have sharp upper boundaries (Figure 3). Such contamination would have blackstained the sediment above the paleosols and probably blurred the upper boundaries of the palesols. For these reasons, we conclude that the age of the bulk (or SOL) fraction is the most reliable in terms of assessing the time when these paleosols were buried.

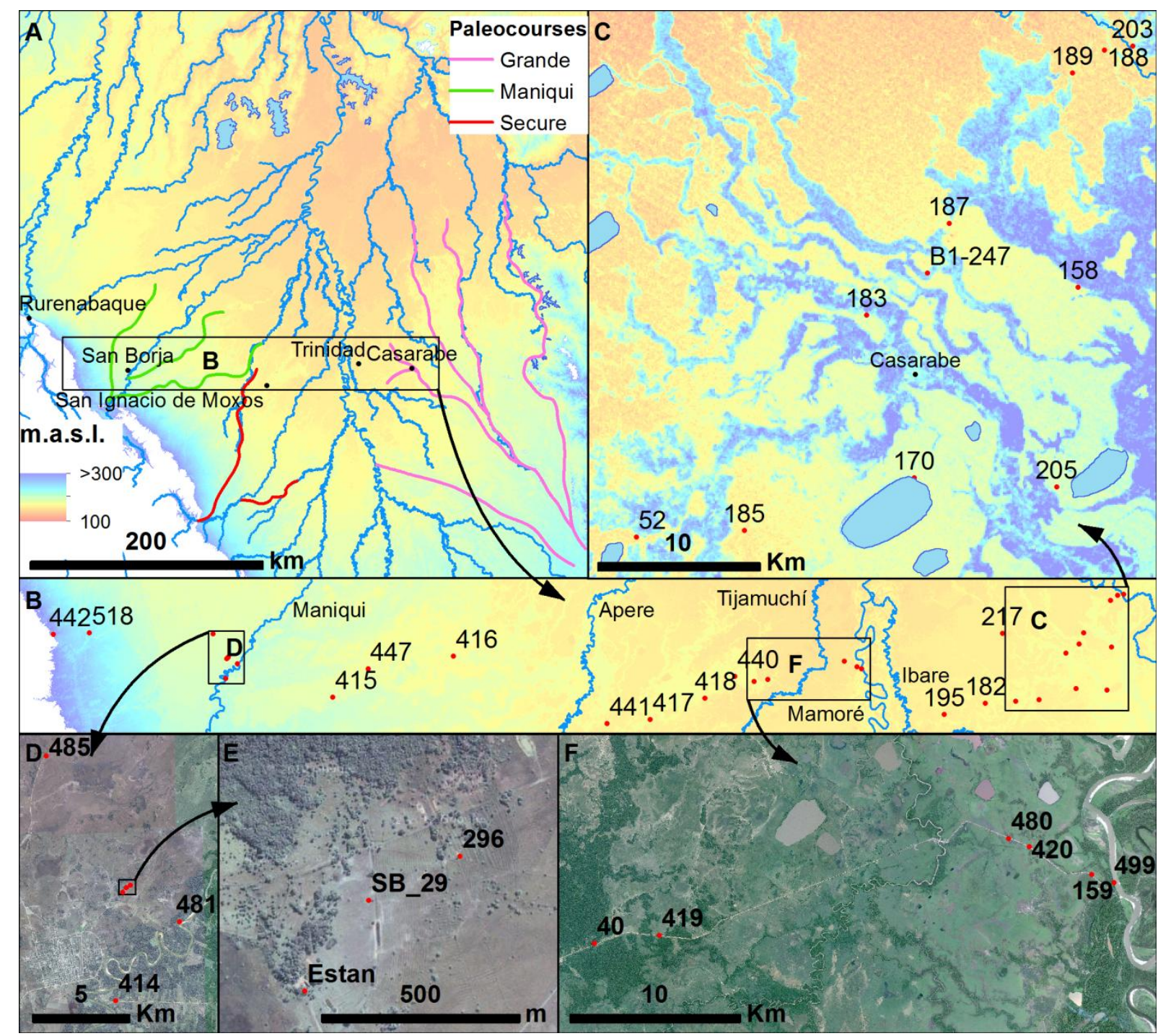

Figure 2 Location of the stratigraphic profiles shown in Figure 4 


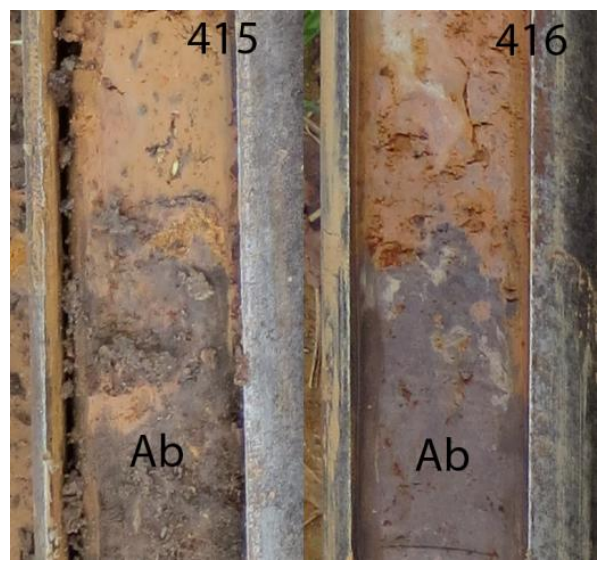

Figure 3 Contact between alluvium and paleosol (Ab) for core 415 and 416.

\section{Results and interpretation}

\subsection{The stratigraphic setting}

The landscape of the central and southern LM has been almost completely reshaped during the Holocene, in some areas, more than once. With the exception of a few cores in the Maniqui and Grande systems, all the cores intercepted at least one paleosol that was buried during the Holocene (Figure 4). 


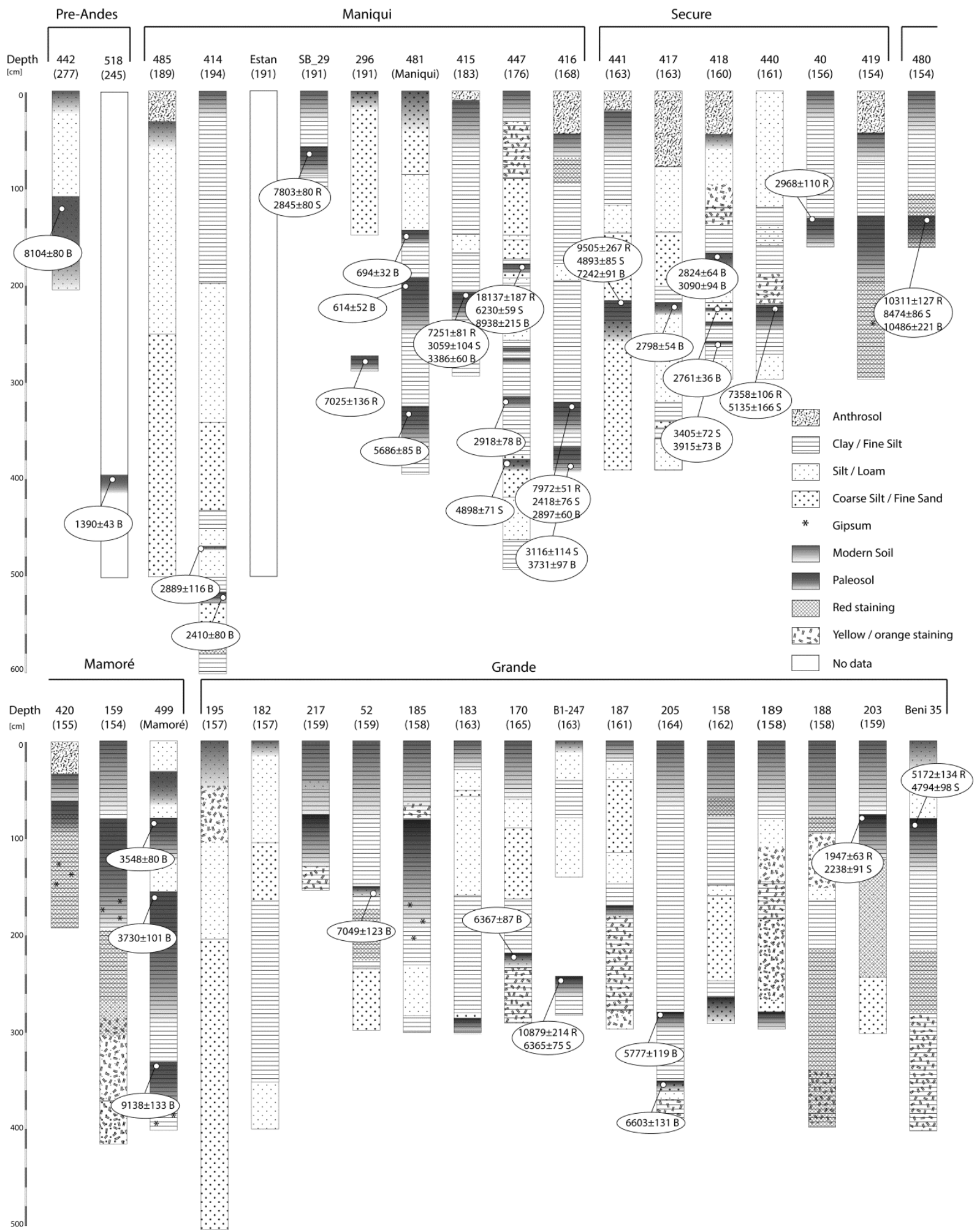

Figure 4 Cored profiles along a $300 \mathrm{~km}$ long transect across the central and southern LM. Location of cores in Figure 2. In ovals the radiocarbon ages of the paleosols in cal yrs BP. R stands for residuals (the humines fraction); $S$ stands for Soluble (the humates fraction); and B stands for Bulk. For full results of the radiocarbon dating see table 1. 
Out of the 36 profiles analysed, 32 contain at least one paleosol (organic rich Ab horizon). A total of 45 paleosols have been identified. The great majority of the profiles reveal intercalations of clays, loams, silts, fine sands and palaeosols of varying thickness, often characterized by sharp boundaries. Paleosols always have sharp upper boundaries, with alluvium covering them (Figure 3 ). Granulometric changes can occur both below and above the paleosols. Sand is mostly fine and in no case we find sediments coarser than sand. In most cases, the core intersected only one paleosol, but in 7 profiles $(194,481,447,416,418,449$, 205) we can identify several distinct organic horizons. While above the paleosols we find weak redoximorphic features, in the sediments below the paleosols we find strong red and orange oxids. Pedogenic gypsum crystals are found in five paleosols (profiles 419, 420, 159, 499 and $185)$, but not in modern soils or in the alluvium covering the paleosols. The association of levee sands and silts, splay sands, backwater loams and clays is characteristic of an avulsive fluvial setting, which is consistent with the formation of megafans in actively subsiding basins (Hartley et al., 2010; Latrubesse et al., 2010; Rossetti et al., 2012; Weissmann et al., 2013; Weissmann et al., 2010). These stratigraphic sequences are also consistent with the region's modern fluvial dynamics (Lombardo, 2016). Amid this general setting, regional differences exist. As expected, a trend towards finer sediments is observed at increasing distance from the Andes. Redoximorphic features are often found in association with clay in the profiles closer to the Mamoré River and to the eastern side of the transect. Based on the location and stratigraphy of the profiles, the transect can be sub-divided into five sub-regions: the preAndean region, which only includes profiles 442 and 518 , and four sub-regions associated to the rivers responsible for most of the sediment deposition: the Maniqui (from 485 to 416); the Sécure (from 441 to 440); the Mamoré (from 40 to 499); and the Grande River (from 195 to Beni 35) (Figure 4).

Most of the Maniqui profiles show stratigraphic patterns typical of avulsive systems. However, differences exist between the group of profiles located to the west of the Maniqui (from 485 to 482$)$ and the rest $(415,447$ and 416$)$. The profiles to the west of the Maniqui show very high diversity. Profiles with thick sand and silt layers that intersect paleosols at a great depth, or that do not contain paleosols at all, are found very close to profiles with paleosols near the surface. For example, the profiles Estan (five meters of sand and silt, no paleosol), SB_29 (clay profile with paleosol at $60 \mathrm{~cm}$ below surface) and 296 (paleosol at $275 \mathrm{~cm}$ below thick fine sand layer) are only a few hundred meters apart (Fig 2E). We interpret this setting as the result of a landscape which was heavily incised during the early to mid- Holocene. The depressions were then filled with alluvium. Profile SB_29 represents the upper part of the ancient landscape, which resisted erosion, while the sand and silts of cores 485, 414 and 296 are the result of the infilling of paleo valleys. Profiles 415,447 and 416 show sequences of varying grain size, similar to 414, 485 and Estan, although the latter two intercept no paleosol. The four cores that did not intercept a paleosol (485, Estan, 195 and 182) are mostly made of sand and silt, indicating highly energetic environments that could have caused the erosion of the ancient paleosols and the deposition of very thick layers of sediment. Profile 447 has five distinct organic horizons which record at least five changes, either avulsions or exceptionally large floods, in the feeding river.

Like the Maniqui, the Sécure also forms a fan as it enters the alluvial plain. However, contrary to the Maniqui fan, the Sécure fan is crossed by other rivers which originate in the alluvial plain 
and flow through the Sécure's paleocourses (for example the Apere River) or are directly connected to the Sécure River, such as the Tijamuchi River (Lombardo, 2016) (Figure 2A,B). The section of the transect that crosses the Sécure sub-region, which comprises cores 441 up to 419 (Fig. 2B,F), is limited by the Apere, to the west, and the Tijamuchi, to the east (Fig 2B). The stratigraphic profiles here are similar to the Maniqui's 415,447 and 416 , with one or more paleosols intercalated with layers of different grainsize. In profiles 441 and 417 the alluvium covering the paleosol gets finer towards the surface, while the opposite is true for profiles 418 and 440. The Mamoré region has remarkably homogeneous profiles. All the Mamoré's profiles have a shallow paleosol covered by clay. The paleosols are found at a depth between 60 and $120 \mathrm{~cm}$ below the surface and overlay clay layers with strong red oxidation and the presence of gypsum crystals, similar to other stratigraphic profiles studied along the banks of the Mamoré River (May et al., 2015). Profile 499, the Mamoré river bank outcrop, has a total of four paleosols. The upper part of the profile comprises two paleosols, a clayey paleosol and a silty paleosol; these are covered by silt recently deposited by the river. A silty layer separates this upper section from the bottom part of the profile, where the other two paleosols are found. Here we only find clay; both the paleosols and the intercalated clay layers show abundant red mottling and gypsum crystals. The presence of gypsum crystals indicates evaporation of ground water (Van Breemen and Buurman, 2002). The absence of gypsum in all the modern soils suggests that modern conditions are wetter than the conditions under which these paleosols formed, which were probably characterized by a longer dry season and/or less rain in the wet season.

These sedimentary sequences are in line with what one would expect in a very active foreland basin, and consistent with what has been already published for the Río Grande system (Lombardo, 2016; Lombardo et al., 2012). Two different depositional environments are identified: the deposition of alluvial sediments over large areas of the floodplain resulting from frequent fluvial avulsions; and the deposition of fine graded sediments along the Mamoré River, now outcropping along its fluvial banks. The first group includes most of the stratigraphic profiles, where deposits of varying grainsize overlay one or more paleosols. Here, sequences of several organic horizons separated by alluvium (for example profiles 447 and 418) probably indicate frequent avulsions and crevasse splays, which are the result of floodplain building processes. The Maniqui, Sécure and Grande fans are responsible for the construction of most of the central and southern LM floodplain (Lombardo, 2016). The second group includes the deposits outcropping along the Mamoré River banks, formed by very fine grained and relatively thick paleosols intercalated by similarly fine grained alluvia. These thick paleosols have already been observed along most of the Mamoré river banks and interpreted as cumulic paleosols, where slow sedimentation is accompanied by soil formation (Lombardo, 2014; May et al., 2015; Plotzki, 2013). We interpret the alluvium interlaced with paleosols as resulting from changes in sedimentation rate (probably related to changes in the frequency or intensity of river overflow) rather than indicative of an avulsive environment, which is quite unlikely for the Mamoré River, as it seems to have experienced only one avulsion, probably in the mid Holocene (Plotzki et al., 2013).

\subsection{The chronology}


The radiocarbon ages of the buried paleosols indicate that most of the sediment deposition occurred between $3815 \pm 73$ cal yrs BP and $2238 \pm 91$ cal yrs. BP. Based on the depth and distribution of the paleosols, it can be concluded that the whole of the SW LM was covered with late Holocene alluvia, in a similar way as the eastern part of the LM, where the Grande River deposited a sedimentary lobe that covered most of the late Pleistocene/early Holocene landscape (Lombardo et al., 2015; Plotzki et al., 2015). More than half of the paleosols dated (18 out of the 32 ) were buried during the late Holocene (Fig. 4). Only three paleosols were buried during the early Holocene. The fact that there are fewer palesols dating to the mid and early Holocene could be the result of not coring deep enough. However, a close examination of the data in Figure 5 suggests that the peak in the number of paleosols observed between $2 \mathrm{~K}$ and $4 \mathrm{~K}$ is real and not a consequence of bias in the coring method. The increase in number of paleosols observed after $4 \mathrm{~K}$ is very sharp, breaking the trend of the older paleosols. Moreover, most of the topmost paleosols aged between $3 \mathrm{~K}$ and $2 \mathrm{~K}$ yrs BP overlay paleosols buried between $4 \mathrm{~K}$ and $2 \mathrm{~K}$ yrs BP, indicating very high river activity between $3 \mathrm{~K}$ and $2 \mathrm{~K}$ yrs $\mathrm{BP}$. A sharp drop in the number of paleosols is observed after $2 \mathrm{~K}$ (Figure 5). In four cases, there is an inversion in the radiocarbon ages. In the case of profile 447, the topmost paleosol is several thousand of years older than the two paleosols below found it. We assumed that this sample was contaminated and for this reason we did not include it in the histogram of figure 5 . In the cases of profiles 414,481 and 418 the inversion is always of few hundreds of years and the paleosols are stratigraphically close. It is likely that in these cases the top paleosol has been deposited shortly after the bottom one, as the presence of relatively coarse sediments between the two paleosols in 414 and 418 also suggests, and the inversion is due to some older carbon deposited within the colluvium.

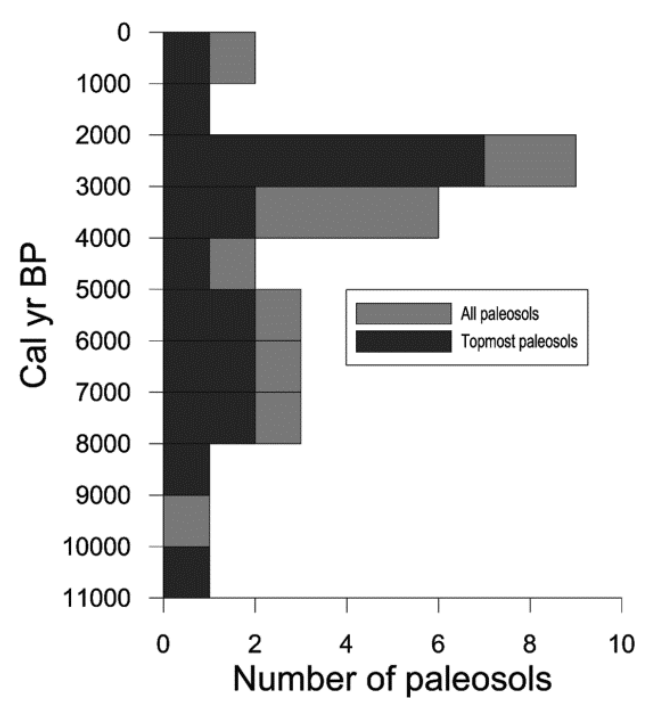

Figure 5 Histogram of number of paleosols ( $\mathrm{X}$ axes) grouped by age (bins are $1 \mathrm{~K}$ yrs.)

Table 1 Radiocarbon ages and C:N values. The error of the calibrated ages is 2 Sigma. The codes "B", " $\mathrm{Hi}$ " and "Ha" after the radiocarbon ages mean bulk, humines and humates and indicate the fraction that has been dated. RAUPD stands for "relative area under probability distribution". Samples marked with "*" have been used in Figure 4; the sample marked with 


\section{" $\mathrm{X}$ " has been excluded from analysis because of probable contamination; sample marked with “N" are those for which no residuals (Humin fraction) could be extracted by the lab.}

\begin{tabular}{|c|c|c|c|c|c|c|c|c|}
\hline Profile & Depth & Lab code & 14C Age & Cal Age & RAUP & $\mathrm{C}[\%]$ & $\mathrm{C}: \mathrm{N}$ & Lat/Long \\
\hline $442 *^{N}$ & $100-110$ & D-AMS 006325 & $7355 \pm 30 \mathrm{~B}$ & $8104 \pm 80$ & 1 & 1.02 & 12.84 & $-14.758391 /-67.171333$ \\
\hline $518^{*}$ & 400 & LARA 6154.1 .1 & $1560 \pm 19 \mathrm{~B}$ & $1390 \pm 43$ & 0.97 & & - & $-14.756264 /-67.07703$ \\
\hline $414^{*}$ & 464 & LARA & $2836 \pm 42 \mathrm{~B}$ & $2889 \pm 116$ & 1 & 0.313 & 4.54 & $-14.878853 /-66.720706$ \\
\hline $414^{*}$ & 532 & LARA & $2408 \pm 26$ B & $2410 \pm 80$ & 0.99 & 0.576 & 5.28 & $-14.878853 /-66.720706$ \\
\hline SB_29 & $60-70$ & D-AMS 006330 & $7034 \pm 31 \mathrm{Hi}$ & $7803 \pm 80$ & 0.8 & 0.285 & 5.67 & $-14.82639 /-66.714925$ \\
\hline SB_29* & $60-70$ & D-AMS 006330 & $2790 \pm 28 \mathrm{Ha}$ & $2845 \pm 80$ & 1 & 0.285 & 5.67 & $-14.82639 /-66.714925$ \\
\hline $296^{*}$ & 270 & D-AMS 006318 & $6163 \pm 41 \mathrm{Hi}$ & $7025 \pm 136$ & 1 & 0.4 & 4.07 & $-14.82541 /-66.712751$ \\
\hline $481^{*}$ & 150 & LARA & $798 \pm 25 B$ & $694 \pm 32$ & 1 & 0.83 & 7.98 & $-14.842767 /-66.68954$ \\
\hline $481^{*}$ & 200 & LARA & $707 \pm 24 \mathrm{~B}$ & $614 \pm 52$ & 1 & 0.656 & 8.63 & $-14.842767 /-66.68954$ \\
\hline $481^{*}$ & 330 & LARA & $5024 \pm 50 \mathrm{~B}$ & $5686 \pm 85$ & 0.75 & 0.375 & 9.87 & $-14.842767 /-66.68954$ \\
\hline 415 & $210-215$ & D_AMS 006322 & $6386 \pm 34 \mathrm{Hi}$ & $7251 \pm 81$ & 0.9 & 0.73 & 11.14 & $-14.931763 /-66.439693$ \\
\hline 415 & $210-215$ & D_AMS 006322 & $2954 \pm 27 \mathrm{Ha}$ & $3059 \pm 104$ & 1 & 0.73 & 11.14 & $-14.931763 /-66.439693$ \\
\hline $415^{*}$ & $210-215$ & LARA 1785.1.1 & $3183 \pm 20 \mathrm{~B}$ & $3386 \pm 60$ & 0.84 & 0.73 & 11.1 & $-14.931763 /-66.439693$ \\
\hline $447^{x}$ & $178-183$ & LARA 3254.1.1 & $8125 \pm 67$ B & $8938 \pm 215$ & 0.92 & 0.38 & $6.37-$ & $-14.860401 /-66.345536$ \\
\hline $447^{x}$ & $178-183$ & D-AMS 006323 & $14967 \pm 51 \mathrm{Hi}$ & $18137 \pm 187$ & 1 & 0.38 & 6.37 & $-14.860401 /-66.345536$ \\
\hline $447^{x}$ & $178-183$ & D-AMS 006323 & $5430 \pm 39 \mathrm{Ha}$ & $6230 \pm 59$ & 0.67 & 0.38 & 6.37 & $-14.860401 /-66.345536$ \\
\hline $447^{*^{N}}$ & $330-334$ & LARA & $2846 \pm 27$ B & $2918 \pm 78$ & 0.95 & 1.938 & 9.45 & $-14.860401 /-66.345536$ \\
\hline $447^{*}$ & $386-391$ & D-AMS 006324 & $4348 \pm 32 \mathrm{~B}$ & $4898 \pm 71$ & 1 & 0.216 & 4.41 & $-14.860401 /-66.345536$ \\
\hline 416 & $335-340$ & D-AMS 006320 & $7178 \pm 35 \mathrm{Hi}$ & $7972 \pm 51$ & 0.9 & 0.95 & 7.73 & $-14.831522 /-66.119951$ \\
\hline 416 & $335-340$ & D-AMS 006320 & $2430 \pm 27 \mathrm{Ha}$ & $2418 \pm 76$ & 0.91 & 0.95 & 7.73 & $-14.831522 /-66.119951$ \\
\hline $416^{*}$ & $335-340$ & LARA 1783.1.1 & $2830 \pm 19 B$ & $2897 \pm 60$ & 0.9 & 0.95 & 7.73 & $-14.831522 /-66.119951$ \\
\hline $416^{N}$ & $390-394$ & D-AMS 006321 & $3010 \pm 27 \mathrm{Ha}$ & $3116 \pm 114$ & 1 & 0.52 & 6.74 & $-14.831522 /-66.119951$ \\
\hline $416^{*}$ & $390-394$ & LARA 1784.1.1 & $3490 \pm 21 \mathrm{~B}$ & $3731 \pm 97$ & 1 & 0.52 & 6.74 & $-14.831522 /-66.119951$ \\
\hline $441^{*}$ & $225-230$ & LARA 6238.1.1 & $6340 \pm 55 \mathrm{~B}$ & $7242 \pm 91$ & 0.85 & 0.19 & 7.66 & $-15.008849 /-65.71791$ \\
\hline 441 & $225-230$ & LARA 6239.1 .1 & $4327 \pm 45 \mathrm{Ha}$ & $4893 \pm 85$ & 0.87 & 0.19 & 7.66 & $-15.008849 /-65.71791$ \\
\hline 441 & $225-230$ & LARA 6240.1 .1 & $8548 \pm 110 \mathrm{Hi}$ & $9505 \pm 267$ & 0.98 & 0.19 & 7.66 & $-15.008849 /-65.71791$ \\
\hline $417^{*}$ & $233-238$ & LARA 6237.1.1 & $2722 \pm 34 \mathrm{~B}$ & $2798 \pm 54$ & 1 & 0.26 & 4.74 & $-15.000101 /-65.604185$ \\
\hline $418^{*^{N}}$ & $165-175$ & LARA 1780.1.1 & $2989 \pm 22$ B & $3090 \pm 94$ & 0.97 & 0.52 & 8.5 & $-14.947707 /-65.45867$ \\
\hline $418^{*^{N}}$ & $227-231$ & LARA & $2681 \pm 26$ B & $2761 \pm 36$ & 0.96 & 0.87 & 7.98 & $-14.947707 /-65.45867$ \\
\hline 418 & $260-265$ & D-AMS 006319 & $3216 \pm 33 \mathrm{Ha}$ & $3405 \pm 72$ & 0.96 & 0.62 & 6.66 & $-14.947707 /-65.45867$ \\
\hline $418^{*}$ & $260-265$ & LARA 1782.1.1 & $3663 \pm 20 B$ & $3915 \pm 73$ & 0.96 & 0.62 & 6.66 & $-14.947707 /-65.45867$ \\
\hline 440 & $235-240$ & POZ-39569 & $6480 \pm 60 \mathrm{Hi}$ & $7358 \pm 106$ & 1 & 1.31 & 10.08 & $-14.892468 /-65.379499$ \\
\hline $440^{*}$ & $235-240$ & POZ-39604 & $4520 \pm 40 \mathrm{Ha}$ & $5135 \pm 166$ & 1 & 1.31 & 10.08 & $-14.892468 /-65.379499$ \\
\hline $40^{*}$ & $120-130$ & Poz-34300 & $2900 \pm 35 \mathrm{Hi}$ & $2968 \pm 110$ & 0.98 & & - & $-14.905046 /-65.329139$ \\
\hline $480^{*}$ & $150-160$ & LARA 6241.1 .1 & $9356 \pm 80 \mathrm{~B}$ & $10486 \pm 221$ & 1 & 0.33 & 5.24 & $-14.851667 /-65.102172$ \\
\hline 480 & $150-160$ & LARA 6242.1.1 & $7719 \pm 45 \mathrm{Ha}$ & $8474 \pm 86$ & 1 & 0.33 & 5.24 & $-14.851667 /-65.102172$ \\
\hline 480 & $150-160$ & LARA 6243.1 .1 & $9158 \pm 63 \mathrm{Hi}$ & $10311 \pm 127$ & 0.96 & 0.33 & 5.24 & $-14.851667 /-65.102172$ \\
\hline 499* & 90 & LARA & $3453 \pm 30 \mathrm{~B}$ & $3648 \pm 80$ & 0.92 & 0.592 & 7.69 & $-14.875451 /-65.04486$ \\
\hline 499* & 160 & LARA & $3491 \pm 29 \mathrm{~B}$ & $3730 \pm 101$ & 0.99 & 0.417 & 5.09 & $-14.875451 /-65.04486$ \\
\hline 499* & 330 & LARA & $8203 \pm 49$ B & $9138 \pm 133$ & 1 & & - & $-14.875451 /-65.04486$ \\
\hline $52^{*}$ & $154-161$ & Poz-34303 & $6200 \pm 40 \mathrm{~B}$ & $7049 \pm 123$ & 0.99 & 0.34 & 5.63 & $-14.962122 /-64.639981$ \\
\hline $170^{*}$ & $224-226$ & Poz-38855 & $5610 \pm 50 \mathrm{~B}$ & $6367 \pm 87$ & 1 & 1.248 & 7.43 & $-14.930284 /-64.480333$ \\
\hline B1-247 & 247 & D-AMS 002335 & $9568 \pm 48 \mathrm{Hi}$ & $10879 \pm 214$ & 1 & & - & $-14.816095 /-64.472081$ \\
\hline B1-247* & 247 & D-AMS 002335 & $5618 \pm 40 \mathrm{Ha}$ & $6365 \pm 75$ & 1 & & - & $-14.816095 /-64.472081$ \\
\hline $205^{*}$ & $292-295$ & Poz-38867 & $5070 \pm 40 \mathrm{~B}$ & $5777 \pm 119$ & 1 & 0.784 & 8.62 & $-14.935759 /-64.398788$ \\
\hline $205^{*}$ & $369-371$ & Poz-38868 & $5840 \pm 40 \mathrm{~B}$ & $6603 \pm 131$ & 1 & 0.316 & 6.58 & $-14.935759 /-64.398788$ \\
\hline $203^{*}$ & 85 & Poz-39599 & $2035 \pm 40 \mathrm{Hi}$ & $1947 \pm 63$ & 1 & 5.056 & 11.6 & $-14.690237 /-64.353773$ \\
\hline 203 & 85 & Poz-39634 & $2245 \pm 40 \mathrm{Ha}$ & $2238 \pm 91$ & 0.99 & 5.056 & 11.6 & $-14.690237 /-64.353773$ \\
\hline Beni35 & 100 & Poz 22767 & $4545 \pm 40 \mathrm{Hi}$ & $5172 \pm 134$ & 0.98 & & - & $-15.123976 /-64.326647$ \\
\hline Beni35* & 100 & Poz- 22766 & $4305 \pm 40 \mathrm{Ha}$ & $4794 \pm 98$ & 0.92 & & - & $-15.123976 /-64.326647$ \\
\hline
\end{tabular}

\section{Discussion}


Most of the landscape of the central and southern LM has been built by the Maniqui, Sécure, Mamoré and Grande rivers during the Holocene. Pollen based climate reconstructions show an increase in precipitation around $4 \mathrm{~K}$ to $3 \mathrm{~K}$ yrs $\mathrm{BP}$, following a relatively dry mid-Holocene (Mayle et al., 2000). For the Río Grande system, it has been suggested that the activation of the fluvial system at the beginning of the Late Holocene was caused by this increase in precipitation (Lombardo et al., 2012). The histogram of the ages of the paleosols shown in Figure 4 seems to support this hypothesis. Reconstructions of past precipitation inferred from oxygen isotopes of Cueva del Tigre Perdido speleothems in Peru (van Breukelen et al., 2008) indicate an increase in the ENSO signal at about 4K BP. The strengthening of el Niño/la Niña cycle, together with the increase in the average precipitation, could have spurred the activation of the river system in the Bolivian Amazon.

In the Maniqui system, where we have three paleosols for which we dated both SOL and RES fractions (SB_29, 415 and 416), the average age of the RES fraction is 7675 cal yrs BP (STDV 377 ) and the average age of the SOL fraction is 2774 cal yrs BP (STDV 326). These small standard deviations suggest that, despite the fact that the paleosols are far apart, they underwent the same processes. If our interpretation of the radiocarbon ages of the two different fractions is correct, this means that these soils formed throughout a long period of several thousand years, which probably included fire episodes, and were all buried at the same time around 2700 years ago, which is considerably later than $4 \mathrm{k}$ yrs BP, when the precipitation reached its maximum and the ENSO signal is strengthened. An abrupt increase in sedimentation rates around $2700 \mathrm{cal} y r$ BP has also been observed in two floodplain systems situated in the lower Amazon River and has been linked to an increased precipitation caused by a negative peak in solar irradiance (Moreira-Turcq et al., 2014). A speleothem from Bahia State in Brazil shows a precipitation peak at 2700 cal BP (Novello et al., 2012). The peak in the number of paleosols that we observe in the histogram in Figure 5 could well be the result of this 2700 cal yr BP event.

The drop in river activity after $2 \mathrm{~K}$ yrs BP is harder to link to climate alone, as it is not evident in the paleoclimate record that important changes happened around $2 \mathrm{~K}$ yrs BP. An important factor that could help explain Holocene river dynamics in the central and southern LM could be neotectonics. It is known that the Bolivian Amazon has undergone several neotectonic subsidence/uplift events, some of them during the Holocene (Lombardo, 2014). A change in the general slope of the alluvial plain due to downriver uplift could explain the increase in river avulsions (Kalliola et al., 1992; Lombardo, 2016; Räsänen et al., 1987; Slingerland and Smith, 2004). In particular, the area to the north of the transect here studied is probably uplifting, as suggested by the presence of underfit rivers and the formation of interior deltas (Lombardo, 2014). The region to the north of the LM is uplifting because of the subduction of the Nazca Ridge (Espurt et al., 2010; Espurt et al., 2007; Lombardo, 2014). This uplift caused the formation of several ria lakes and repeated changes in the course of the Beni River (Dumont, 1993; Dumont and Fournier, 1994; Hanagarth, 1993; Lombardo, 2014). Unfortunately, we know very little about the timing and location of the Holocene neotectonic events in Western Amazonia. Further research is needed in order to understand to what extent neotectonics has 
contributed to shape river dynamics and the evolution of the landscape in the Bolivian Amazon throughout the Holocene.

\subsection{Impact of river activity on pre-Columbian settlement patterns and the preservation of the archaeological record}

The timing of paleosol formation in the LM matches the timing of human occupation, as inferred from the archaeological evidence in the MMR in the eastern LM. People inhabited this area since the early Holocene and created shell middens, prehistoric waste dumps, which later became elevated patches of forest in the savannah, today known as forest islands (Lombardo et al., 2013b). After two thousand years of archaeological hiatus (from $4 k$ to $2 k$ cal. yrs BP), which matches the period of highest river activity in the region, agriculturists reoccupied the Bolivian Amazon. River avulsions are likely to be catastrophic, because while they suddenly flood and cover with alluvium new areas, old rivers become abandoned, with detrimental effects on the people living along them, as recent and historical cases show (Lombardo, 2016; Pärssinen et al., 1996). We know that the three early Holocene sites for which we have a chronology (Lombardo et al., 2013b), where abandoned probably because of the catastrophic effect of the Río Grande avulsion. However, as these sites are relatively close to each other, it is very difficult at this stage to say what happen to their inhabitants. Did they just move to areas a few tens of kilometres away? Did they migrate to areas of the Llanos de Moxos that are less prone to catastrophic floods? Did they migrate elsewhere? The abandonment of these sites coincides with the expansion of pre-ceramic sites in the area of the Pantanal (Iriarte et al., 2016; Peixoto, 2003), suggesting a possible migration from the Llanos de Moxos towards these areas." More archaeological research is needed to reconstruct the migration routes of these pre-ceramic groups at the end of the mid-Holocene. The late Holocene re-occupation of the LM was characterized by a rich diversity of earthworks and agricultural strategies that, in some cases (Lombardo et al., 2015; Lombardo et al., 2012), took advantage of the recently deposited fertile alluvium. These late Holocene "moundbuilders" deeply transformed the landscape by building monumental mounds, causeways, drainage and irrigation canals (Lombardo and Prümers, 2010; Prümers and Jaimes Betancourt, 2014). Through the construction of these earthworks, pre-Columbians changed the local and, in some areas, the regional hydrology. The Bolivian Amazon is a striking example of pre-Columbian human - environment interactions where changes in the hydrology shaped settlement patterns and, in turn, human engineering of the landscape changed the hydrology.

An important part of the LM is covered with Late Holocene earthworks (Figure 7). In the MMR, these are strongly linked to the paleochannels of the Río Grande fan, with the monumental mounds built on the inner side of the abandoned meanders and the paleochannels often crossed by canals and causeways (Lombardo and Prümers, 2010). This archaeological evidence indicates that rivers have not been very active in more recent times, at least since the construction of the earthworks around $2 \mathrm{k}$ yrs BP. The timing of the construction of the vast late-Holocene pre-Columbian earthworks (Denevan, 1966; Erickson, 2000; Jaimes Betancourt, 2016; Lombardo et al., 2011b; Prümers and Jaimes Betancourt, 2014) coincides with the drop in river activity around $2 \mathrm{~K}$ yr BP, as inferred from the paleosol sedimentary record (Figure 6). This is not the case, however, in the region closer to the Andean piedmont, rivers within 60-70 $\mathrm{km}$ from the piedmont have probably always been very active (Lombardo, 2017), as shown by 
the $1390 \pm 43$ cal yr BP paleosol in profile 518 , which is found below 4 meters of sediment and in association with pottery. While the late Holocene archaeological record has not been greatly affected by river activity, the same cannot be said for the early and mid-Holocene record. As the stratigraphy of the Isla del Tesoro shell mound (Lombardo et al., 2013b), figure 7, and the transect in Figure 4 show, most of the early and mid-Holocene soils (and the archaeological sites built on them) have been buried by alluvium over a large portion of the LM. This results in a very fragmented pre-ceramic archaeological record in the central and southern $L M$, where only the most elevated sites are still visible in the landscape today, such as the 2 meter high Isla del Tesoro, in the central LM. This introduces a "size bias", where only the highest sites can be found and studied by archaeologists. Moreover, the size bias is not constant throughout the territory, as it depends on the thickness of the alluvium that buried them. In the areas belonging to the Maniqui or Sécure fans, where often paleosols are buried under more than three meters of sediment, it is likely that all the early and mid-Holocene archaeological record has been lost. It has been suggested that the mid-Holocene archaeological hiatus in Amazonia (the lack of mid-Holocene archaeological sites despite well documented and abundant Late Holocene sites) could be due to the fact that earlier sites have been buried by alluvial deposits (Neves, 2008). The data from the Llanos de Moxos here presented supports this hypothesis.

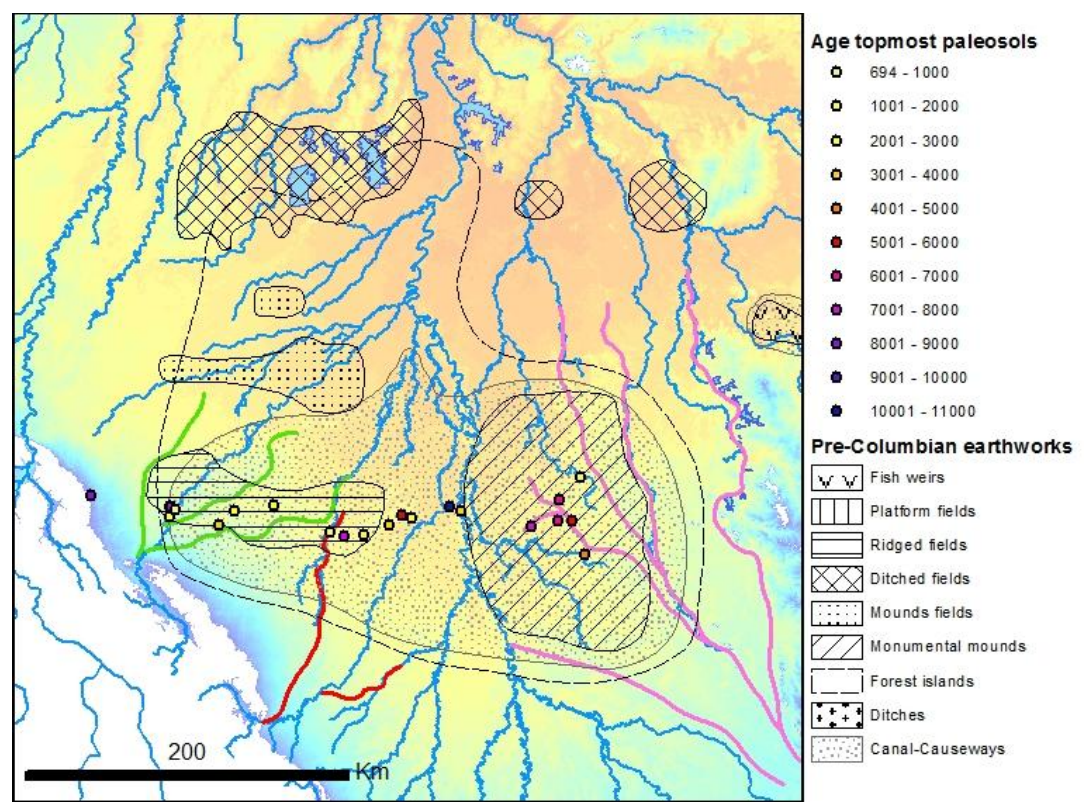

Figure 6 Geographic distributions of the binned ages of the uppermost paleosol shown in Figure 5 and location of pre-Columbian earthworks based on (Lombardo et al., 2011b) and (Rodrigues et al., In press). 


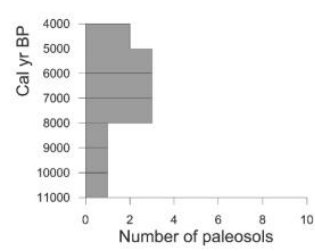

Early and mid-Holocene

River activity is low from the beginning of the Holocene til $4 \mathrm{k}$ cal. BP. Soil forms, people settle here and build the Isla del Tesoro shell

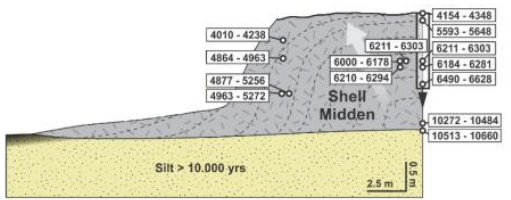
midden
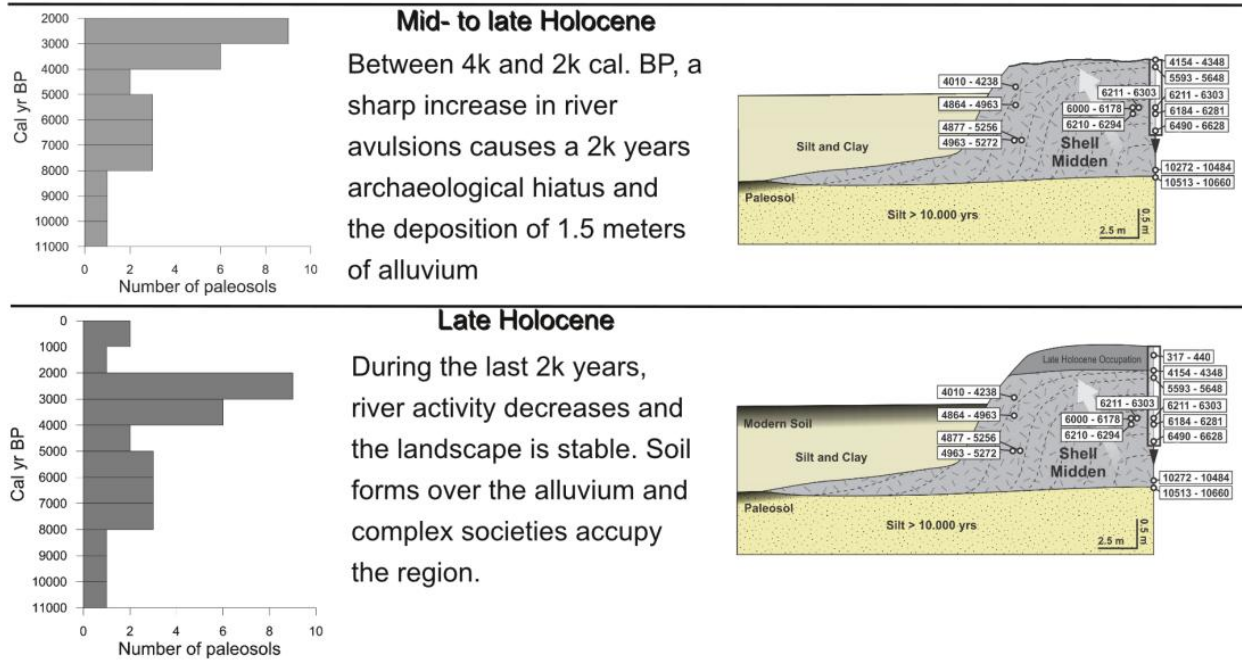

During the last $2 \mathrm{k}$ years, river activity decreases and the landscape is stable. Soil forms over the alluvium and complex societies accupy

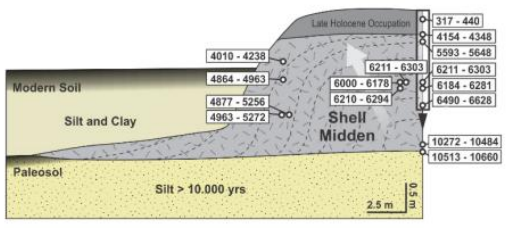
the region.

Figure 7 Comparison between fluvial dynamics in central Llanos de Moxos and soil formation and human occupation at Isla del Tesoro site. Based on (Lombardo et al., 2013b)

\section{Conclusions}

This paper reconstructs Holocene fluvial dynamics in SW Amazonia trough the analysis of 36 stratigraphic profiles taken along a $300 \mathrm{~km}$ long transect across the Bolivian lowlands. Based on 50 radiocarbon ages from paleosols intercalated with fluvial sediments, we reconstruct, on a millennial scale, the most important changes in the region's floodplain dynamics. Fluvial activity is low from 10k cal. yrs BP to $4 k$ cal. yrs BP and increases significantly from $4 k$ to $2 k$ cal yrs BP (with a peak around 2700 cal yrs BP) causing high rates of river avulsions and the formation of crevasse splays. Fluvial activity sharply decreases after $2 \mathrm{k}$ cal BP. The paleosol record matches existing climate reconstructions; however, further research is needed in order to assess the influence of neotectonics on the region's fluvial dynamics during the Holocene. Rivers had a paramount impact on pre-Columbian people and the archaeological record. The periods of human occupation coincide with periods of limited fluvial activity, while an archaeological hiatus from $4 \mathrm{k}$ to $2 \mathrm{k}$ cal yr BP is synchronous with a sharp increase in river avulsions and sediment deposition. Most of the early and mid-Holocene archaeological sites in the central and southern LM are likely to have been buried by alluvium; while, the abundance of late Holocene earthworks suggests relative stability and limited river activity during the last $2 \mathrm{~K}$ yrs.

\section{Acknowledgments}


This work was supported by the Swiss National Science Foundation (SNSF) [grants no P300P2158459/1, 200020-141277/1, and 200021-122289] and by the European Union's Horizon 2020 research and innovation programme [Marie Skłodowska-Curie actions, EU project 703045]. We would like to thank Alena Giesche, Anna Plotzki, Bernhard Vogt, Christoph Welker, and Nick Zihlmann for helping in the field, and Elisa Canal-Beeby who helped improve earlier versions of the manuscript.

\section{References}

Aalto, R., Dunne, T., Nittrouer, C.A., Maurice-Bourgoin, L., Montgomery, D.R., 2002. Fluvial transport of sediment across a pristine tropical foreland basin: channel-floodplain interaction and episodic floodplain deposition., in: Dyer, F.J., Thoms, M.C., Olley, J.M. (Eds.), The Structure, Function and Management Implication of Fluvial Sedimentary Systems. IAHS Publication, pp. 339-344.

Aalto, R., Maurice-Bourgoin, L., Dunne, T., Montgomery, D.R., Nittrouer, C.A., Guyot, J.-L., 2003. Episodic sediment accumulation on Amazonian flood plains influenced by $\mathrm{El}$ Niño/Southern Oscillation. Nature 425, 493-497.

Ayres, J.M., Clutton-Brock, T.H., 1992. River Boundaries and Species Range Size in Amazonian Primates. The American Naturalist 140, 531-537.

Bert, F., Corella, A., Gené, M., Pérez-Pérez, A., Turbón, D., 2004. Mitochondrial DNA diversity in the Llanos de Moxos: Moxo, Movima and Yuracare Amerindian populations from Bolivia lowlands. Ann. Hum. Biol. 31, 9-28.

Brugger, S.O., Gobet, E., van Leeuwen, J.F.N., Ledru, M.-P., Colombaroli, D., van der Knaap, W.O., Lombardo, U., Escobar-Torrez, K., Finsinger, W., Rodrigues, L., Giesche, A., Zarate, M., Veit, H., Tinner, W., 2016. Long-term man-environment interactions in the Bolivian Amazon: 8000 years of vegetation dynamics. Quaternary Science Reviews 132, 114-128.

Bush, M.B., Silman, M.R., 2007. Amazonian exploitation revisited: ecological asymmetry and the policy pendulum. Frontiers in Ecology and the Environment 5, 457-465.

Carson, J.F., Whitney, B.S., Mayle, F.E., Iriarte, J., Prümers, H., Soto, J.D., Watling, J., 2014. Environmental impact of geometric earthwork construction in pre-Columbian Amazonia. Proceedings of the National Academy of Sciences.

Crevels, E.I., van der Voort, H.G.A., 2008. The Guaporé-Mamoré region as a linguistic area, in: Muysken, P.C. (Ed.), From linguistic areas to areal linguistics. John Benjamins Publishing Company, Amsterdam/Philadelphia, pp. 151-179.

Denevan, W.M., 1966. The Aboriginal Cultural Geography of the Llanos de Mojos of Bolivia. University of California Press, Berkeley.

Denevan, W.M., 1996. A bluff model of riverine settlement in prehistoric Amazonia. Annals of the Association of American Geographers 86, 654-681.

Dumont, J.F., 1993. Type of lakes as related to neotectonics in western Amazonia, International symposium on the Quaternary of Amazonia, 8-13 November 1992. Universidade de Amazonas, Manaus, Brazil.

Dumont, J.F., Fournier, M., 1994. Geodynamic environment of Quaternary morphostructures of the subandean foreland basins of Peru and Bolivia: Characteristics and study methods.

Quaternary International 21, 129-142.

Erickson, C.L., 2000. An artificial landscape-scale fishery in the Bolivian Amazon. Nature 408, 190-193.

Erickson, C.L., 2008. Amazonia: the historical ecology of a domesticated landscape, in:

Silverman, H., Isbell, W.H. (Eds.), Handbook of South American archaeology. Springer, Berlin, pp. 157-183. 
Erickson, C.L., Walker, J.H., 2009. Precolumbian causeways and canals as landesque capital, in: Snead, J.E., Erickson, C.L., Darling, J.A. (Eds.), Landscapes of movement. University of Pennsylvania Museum of Archaeology and Anthropology, Philadelphia.

Espurt, N., Baby, P., Brusset, S., Roddaz, M., Hermoza, W., Barbarand, J., 2010. The Nazca Ridge and Uplift of the Fitzcarrald Arch: Implications for Regional Geology in Northern South America, in: Hoorn, C., Wesselingh, F.P. (Eds.), Amazonia: Landscape and Species Evolution. Wiley-Blackwell Publishing Ltd., Oxford, UK, pp. 89-100.

Espurt, N., Baby, P., Brusset, S., Roddaz, M., Hermoza, W., Regard, V., Antoine, P.O., SalasGismondi, R., Bolaños, R., 2007. How does the Nazca Ridge subduction influence the modern Amazonian foreland basin? Geology 35, 515-518.

Ferreira, L.V., Stohlgren, T.J., 1999. Effects of river level fluctuation on plant species richness, diversity, and distribution in a floodplain forest in Central Amazonia. Oecologia 120, 582-587. Gautier, E., Brunstein, D., Vauchel, P., Jouanneau, J.-M., Roulet, M., Garcia, C., Guyot, J.-L., Castro, M., 2010. Channel and floodplain sediment dynamics in a reach of the tropical meandering Rio Beni (Bolivian Amazonia). Earth Surface Processes and Landforms 35, 18381853.

Goh, K.M., Molloy, B.P.J., 1978. RADIOCARBON DATING OF PALEOSOLS USING SOIL ORGANIC MATTER COMPONENTS. Journal of Soil Science 29, 567-573.

Hamilton, S.K., Sippel, S.J., Melack, J.M., 2004. Seasonal inundation patterns in two large savanna floodplains of South America: the Llanos de Moxos(Bolivia) and the Llanos del Orinoco(Venezuela and Colombia). Hydrological Processes 18, 2103-2116.

Hanagarth, W., 1993. Acerca de la geoecología de las sabanas del Beni en el noreste de Bolivia. Instituto de ecología, La Paz.

Hartley, A.J., Weissmann, G.S., Nichols, G.J., Warwick, G.L., 2010. Large Distributive Fluvial Systems: Characteristics, Distribution, and Controls on Development. Journal of Sedimentary Research 80, 167-183.

Hijmanns, R.J., Cameron, S.E., Parra, J.L., Jones, P.G., Jarvis, A., 2005. Very high resolution interpolated climate surfaces for global land areas. International Journal of Climatology 25, 1965-1978.

Hilbert, L., Neves, E.G., Pugliese, F., Whitney, B.S., Shock, M., Veasey, E., Zimpel, C.A., Iriarte, J., 2017. Evidence for mid-Holocene rice domestication in the Americas. Nature Ecology \& Evolution 1, 1693-1698.

Hogg, A.G., Hua, Q., Blackwell, P.G., Niu, M., Buck, C.E., Guilderson, T.P., Heaton, T.J., Palmer, J.G., Reimer, P.J., Reimer, R.W., Turney, C.S.M., Zimmerman, S.R.H., 2013. SHCal13 Southern Hemisphere Calibration, 0-50,000 Years cal BP. Radiocarbon 55, 1889-1903.

Iriarte, J., DeBlasis, P., De Souza, J.G., Corteletti, R., 2016. Emergent Complexity, Changing Landscapes, and Spheres of Interaction in Southeastern South America During the Middle and Late Holocene. Journal of Archaeological Research, 1-63.

Iriarte, J., Smith, R.J., Souza, J.G.d., Mayle, F.E., Whitney, B.S., Cárdenas, M.L., Singarayer, J., Carson, J.F., Roy, S., Valdes, P., 2017. Out of Amazonia: Late-Holocene climate change and the Tupi-Guarani trans-continental expansion. The Holocene 27, 967-975.

Jaimes Betancourt, C., 2013. Diversidad cultural en los Llanos de Mojos, in: Valdez, F. (Ed.), Arqueología Amazónica. Abya-Yala, Quito- Ecuador.

Jaimes Betancourt, C., 2016. Dos fases cerámicas de la cronología ocupacional de las zanjas de la provincia Iténez - Beni, Bolivia, in: Barreto, C., Pinto Lima, H., Jaimes Betancourt, C. (Eds.), Cerâmicas Arqueologicas de Amazônia. IPHAN - Ministério de Cultura, Belém, pp. 435-447. Junk, W., 2013. Current state of knowledge regarding South America wetlands and their future under global climate change. Aquatic Sciences - Research Across Boundaries 75, 113-131. Junk, W.J., 1984. Ecology of the várzea, floodplain of Amazonian whitewater rivers, in: Sioli, H. (Ed.), The Amazon: Limnology and landscape ecology of a mighty tropical river and its basin. Springer Netherlands, Dordrecht, pp. 215-243. 
Kalliola, R., Salo, J., Puhakka, M., Rajasilta, M., Häme, T., Neller, R.J., Räsänen, M.E., Danjoy Arias, W.A., 1992. Upper amazon channel migration. Naturwissenschaften 79, 75-79. Langstroth, R.P., 2011. Biogeography of the Llanos de Moxos: natural and anthropogenic determinants. Geographica Helvetica 66, 183-192.

Lathrap, D.W., 1968. Aboriginal Occupation and Changes in River Channel on the Central Ucayali, Peru. American Antiquity 33, 62-79.

Latrubesse, E.M., Cozzuol, M., da Silva-Caminha, S.A.F., Rigsby, C.A., Absy, M.L., Jaramillo, C., 2010. The Late Miocene paleogeography of the Amazon Basin and the evolution of the Amazon River system. Earth-Science Reviews 99, 99-124.

Lombardo, U., 2014. Neotectonics, flooding patterns and landscape evolution in southern Amazonia. Earth Surf. Dynam. 2, 493-511.

Lombardo, U., 2016. Alluvial plain dynamics in the southern Amazonian foreland basin. Earth Syst. Dynam. 7, 453-467.

Lombardo, U., 2017. River logjams cause frequent large-scale forest die-off events in southwestern Amazonia. Earth Syst. Dynam. 8, 565-575.

Lombardo, U., Canal-Beeby, E., Fehr, S., Veit, H., 2011a. Raised fields in the Bolivian Amazonia: a prehistoric green revolution or a flood risk mitigation strategy? Journal of Archaeological Science 38, 502-512.

Lombardo, U., Canal-Beeby, E., Veit, H., 2011b. Eco-archaeological regions in the Bolivian Amazon: Linking pre-Columbian earthworks and environmental diversity Geographica Helvetica 66, 173-182.

Lombardo, U., Denier, S., May, J.-H., Rodrigues, L., Veit, H., 2013a. Human-environment interactions in pre-Columbian Amazonia: The case of the Llanos de Moxos, Bolivia. Quaternary International 312, 109-119.

Lombardo, U., Denier, S., Veit, H., 2015. Soil properties and pre-Columbian settlement patterns in the Monumental Mounds Region of the Llanos de Moxos, Bolivian Amazon. SOIL 1, 65-81. Lombardo, U., May, J.-H., Veit, H., 2012. Mid- to late-Holocene fluvial activity behind preColumbian social complexity in the southwestern Amazon basin. The Holocene 22, 1035-1045. Lombardo, U., Prümers, H., 2010. Pre-Columbian human occupation patterns in the eastern plains of the Llanos de Moxos, Bolivian Amazonia. Journal of Archaeological Science 37, 18751885.

Lombardo, U., Szabo, K., Capriles, J.M., May, J.-H., Amelung, W., Hutterer, R., Lehndorff, E., Plotzki, A., Veit, H., 2013b. Early and Middle Holocene Hunter-Gatherer Occupations in Western Amazonia: The Hidden Shell Middens. PLoS ONE 8, e72746.

Lowe, J.J., Walker, M.J., 1997. Reconstructing quaternary environments 2 nd edition. Pearson Education Limited, Harlow, UK.

Marengo, J.A., 2008. The Drought of Amazonia in 2005. Journal of Climate 21, 495-516.

May, J.-H., Plotzki, A., Rodrigues, L., Preusser, F., Veit, H., 2015. Holocene floodplain soils along the Río Mamoré, northern Bolivia, and their implications for understanding inundation and depositional patterns in seasonal wetland settings. Sedimentary Geology 330, 74-89.

Mayle, F.E., Burbridge, R., Killeen, T.J., 2000. Millennial-scale dynamics of southern Amazonian rain forests. Science 290, 2291-2294.

Mayle, F.E., Langstroth, R.P., Fisher, R.A., Meir, P., 2007. Long-term forest-savannah dynamics in the Bolivian Amazon: implications for conservation. Philosophical Transactions of the Royal Society B: Biological Sciences 362, 291-307.

McGrath, D.G., de Castro, F., Futemma, C., de Amaral, B.D., Calabria, J., 1993. Fisheries and the evolution of resource management on the lower Amazon floodplain. Human Ecology 21, $167-$ 195.

McMichael, C.H., Palace, M.W., Bush, M.B., Braswell, B., Hagen, S., Neves, E.G., Silman, M.R., Tamanaha, E.K., Czarnecki, C., 2014. Predicting pre-Columbian anthropogenic soils in Amazonia. Proceedings of the Royal Society B: Biological Sciences 281. 
Meentemeyer, V., 1978. Macroclimate the Lignin Control of Litter Decomposition Rates. Ecology 59, 465-472.

Meggers, B.J., 1971. Amazonia: man and culture in a counterfeit paradise. Aldine-Atherton, Chicago.

Meggers, B.J., 2007. Mid-Holocene climate and cultural dynamics in Brazil and the Guianas, in: Anderson, D.G., Maasch, K.A., Sandweiss, D.H. (Eds.), Climate change \& cultural dynamics. Elsevier, Amsterdam, pp. 117-155.

Melack, J., Hess, L., 2011. Remote Sensing of the Distribution and Extent of Wetlands in the Amazon Basin, in: Junk, W.J., Piedade, M.T.F., Wittmann, F., Schöngart, J., Parolin, P. (Eds.), Amazonian Floodplain Forests. Springer Netherlands, pp. 43-59.

Moreira-Turcq, P., Turcq, B., Moreira, L.S., Amorim, M., Cordeiro, R.C., Guyot, J.L., 2014. A 2700calyr BP extreme flood event revealed by sediment accumulation in Amazon floodplains. Palaeogeography, Palaeoclimatology, Palaeoecology 415, 175-182.

Müller, R., Müller, D., Schierhorn, F., Gerold, G., 2011. Spatiotemporal modeling of the expansion of mechanized agriculture in the Bolivian lowland forests. Applied Geography 31, 631-640.

Neves, E.G., 2008. Ecology, Ceramic Chronology and Distribution, Long-term History, and Political Change in the Amazonian Floodplain, in: Silverman, H., Isbell, W.H. (Eds.), Handbook of South American archaeology. Springer, Berlin, pp. 359-379.

Novello, V.F., Cruz, F.W., Karmann, I., Burns, S.J., Stríkis, N.M., Vuille, M., Cheng, H., Lawrence Edwards, R., Santos, R.V., Frigo, E., Barreto, E.A.S., 2012. Multidecadal climate variability in Brazil's Nordeste during the last 3000 years based on speleothem isotope records. Geophysical Research Letters 39, n/a-n/a.

Pacheco, P., 2006. Agricultural expansion and deforestation in lowland Bolivia: the import substitution versus the structural adjustment model. Land Use Policy 23, 205-225.

Pärssinen, M.H., Salo, J.S., Räsänen, M.E., 1996. River floodplain relocations and the abandonment of Aborigine settlements in the Upper Amazon Basin: A historical case study of San Miguel de Cunibos at the Middle Ucayali River. Geoarchaeology 11, 345-359.

Peixoto, J.L.S., 2003. A ocupação dos povos indígenas pré-coloniais nos grandes lagos do Pantanal Sul-mato-grossense, Faculdade de Filosofia e Ciências Humanas. Pontifícia Universidade Católica do Rio Grande do Sul, Porto Alegre.

Plafker, G., 1964. Oriented Lakes and Lineaments of Northeastern Bolivia. Geological Society of America Bulletin 75, 503-522.

Plotzki, A., 2013. Late Pleistocene to Holocene fluvial dynamics and environmental conditions in the Llanos de Moxos, Bolivian Amazon, Philosophisch naturwissenschaftlichen Fakultät. Universität Bern, Bern.

Plotzki, A., May, J.H., Preusser, F., Roesti, B., Denier, S., Lombardo, U., Veit, H., 2015.

Geomorphology and evolution of the late Pleistocene to Holocene fluvial system in the southeastern Llanos de Moxos, Bolivian Amazon. Catena 127, 102-115.

Plotzki, A., May, J.H., Preusser, F., Veit, H., 2013. Geomorphological and sedimentary evidence for late Pleistocene to Holocene hydrological change along the Río Mamoré, Bolivian Amazon. Journal of South American Earth Sciences 47, 230-242.

Post, W.M., Pastor, J., Zinke, P.J., Stangenberger, A.G., 1985. Global patterns of soil nitrogen storage. Nature 317, 613-616.

Prümers, H., Jaimes Betancourt, C., 2014. 100 años de investigación arqueológica en los Llanos de Mojos. Arqueoantropológicas 4, 11-53.

Räsänen, M.E., Salo, J.S., Kalliola, R.J., 1987. Fluvial Perturbance in the Western Amazon Basin: Regulation by Long-Term Sub-Andean Tectonics. Science 238, 1398-1401.

Remsen, J.V., Parker, T.A., 1983. Contribution of River-Created Habitats to Bird Species Richness in Amazonia. Biotropica 15, 223-231. 
Roche, M.A., Fernândez-Jâuregui, C., Aliaga, A., Bourges, J., Cortes, C., Guyot, J.L., Pena, J., Rocha, N., 1991. Water and salt balances of the Bolivian Amazon, in: Braga, B.P.F., FernándezJáuregui, C.A. (Eds.), Water Management of the Amazon Basin. UNESCO-ROSTLAC, pp. 83-94. Rodrigues, L., Lombardo, U., Fehr, S., Preusser, F., Veit, H., 2015. Pre-Columbian agriculture in the Bolivian Lowlands: Construction history and management of raised fields in Bermeo. Catena 132, 126-138.

Rodrigues, L., Lombardo, U., Trauerstein, M., Huber, P., Mohr, S., Veit, H., 2016. An insight into pre-Columbian raised fields: the case of San Borja, Bolivian lowlands. SOIL 2, 367-389.

Rodrigues, L., Lombardo, U., Veit, H., In press. Design of pre-Columbian raised fields in the Llanos de Moxos, Bolivian Amazon: Differential adaptations to the local environment? Journal of Archaeological Science: Reports.

Rossetti, D.F., Zani, H., Cohen, M.C.L., Cremon, É.H., 2012. A Late Pleistocene-Holocene wetland megafan in the Brazilian Amazonia. Sedimentary Geology 282, 276-293.

Salo, J., Kalliola, R., Hakkinen, I., Makinen, Y., Niemela, P., Puhakka, M., Coley, P.D., 1986. River dynamics and the diversity of Amazon lowland forest. Nature 322, 254-258.

Schmidt, M.W.I., Torn, M.S., Abiven, S., Dittmar, T., Guggenberger, G., Janssens, I.A., Kleber, M., Kogel-Knabner, I., Lehmann, J., Manning, D.A.C., Nannipieri, P., Rasse, D.P., Weiner, S., Trumbore, S.E., 2011. Persistence of soil organic matter as an ecosystem property. Nature 478, 49-56.

Schwendel, A.C., Nicholas, A.P., Aalto, R.E., Smith, G.H.S., Buckley, S., 2015. Interaction between meander dynamics and floodplain heterogeneity in a large tropical sand-bed river: the Rio Beni, Bolivian Amazon. Earth Surface Processes and Landforms 40, 2026-2040.

Slingerland, R., Smith, N.D., 2004. River Avulsions and their deposits. Annual Review of Earth and Planetary Sciences 32, 257-285.

Sponsel, E.L., 1986. Amazon Ecology and Adaptation. Annual Review of Anthropology 15, 6797.

Van Breemen, N., Buurman, P., 2002. Soil formation, 2nd edition. Springer.Science+Businness Media, B.V.

van Breukelen, M.R., Vonhof, H.B., Hellstrom, J.C., Wester, W.C.G., Kroon, D., 2008. Fossil dripwater in stalagmites reveals Holocene temperature and rainfall variation in Amazonia. Earth and Planetary Science Letters 275, 54-60.

Walker, J., 2004. Agricultural Change in the Bolivian Amazon. University of Pittsburgh Latin American Archaeology Publications and Fundación Kenneth Lee, Trinidad.

Wang, Y., Amundson, R., Trumbore, S., 1996. Radiocarbon dating of soil organic matter. Quaternary Research 45, 282-288.

Weissmann, G., Hartley, A., Scuderi, L., Nichols, G., Davidson, S., Owen, A., Atchley, S., Bhattacharya, J., Chakraborty, T., Ghosh, P., 2013. Prograding distributive fluvial systems: geomorphic models and ancient examples. New Frontiers in Paleopedology and Terrestrial Paleoclimatology: SEPM, Special Publication 104, 131-147.

Weissmann, G.S., Hartley, A.J., Nichols, G.J., Scuderi, L.A., Olson, M., Buehler, H., Banteah, R., 2010. Fluvial form in modern continental sedimentary basins: Distributive fluvial systems.

Geology 38, 39-42.

Whitney, B.S., Dickau, R., Mayle, F.E., Walker, J.H., Soto, J.D., Iriarte, J., 2014. Pre-Columbian raised-field agriculture and land use in the Bolivian Amazon. The Holocene. 